ISSN-0253-7214

\title{
EFFECTS OF ALTITUDE, ROOT BIOMASS AND TEMPERATURE OF SOIL ON BIOMASS OF EARTHWORM IN SOUTH-EASTERN PART OF SIMILIPAL BIOSPHERE RESERVE, MAYURBHANJ, ODISHA
}

\author{
M.K. Lenka ${ }^{1 *}$ and N. Mohanty ${ }^{1}$ \\ ${ }^{1}$ P.G. Dept. of Zoology, North Orissa University, Baripada, 757 003, Odisha, India. \\ "E-mail: lenkamahesh@gmail.com
}

\begin{abstract}
Earthworm is the most important invertebrate of soil. Since it involved in improving the soil quality, an attempt has been made to test the effects of root biomass and temperature of soil on density of earthworms in different altitudes of South-eastern part of Similipal Biosphere Reserve (SBR) (Balma: 133 mASL, Debkund: 190 mASL, Hadgut: $222 \mathrm{mASL}$, Katuria: $242 \mathrm{mASL}$ and Nato: $326 \mathrm{mASL}$ ). It was observed that the biomass (weight) of earthworms is significantly different among different seasons. But among altitudes it was not significantly different (Tables: 1). More root biomass indicates higher earthworm biomass. Biomass of earthworm was highest at moderate temperature, i.e., in rainy season (since temperature of soil in rainy was more than that of winter and less than that of summer season). There was a significant difference $(\mathrm{p}<0.05)$ in biomass of earthworm among different seasons of study areas.
\end{abstract}

KEYWORDS: Earthworm, Biomass, Root Biomass, Altitude, Temperature.

\section{INTRODUCTION}

Soil is a treasure house of different type of invertebrates and to lesser extent vertebrates. Earthworms are the most important soil invertebrate. Traditionally earthworms were used in fishing. But nowa-days earthworm has a wide range of application in agriculture and in many more fields. It plays a vital role in the increase of soil fertility. Earthworm has a significant role in soil aggregation and soil porosity 3,22. Therefore, Aristotle rightly called them as "Nature's Plough". So, indirectly it also helps in the increase of soil aeration, water infiltration, water-holding capacity, soil tilt and in soil crusting ${ }^{8}$. Earthworms are involved in improving the soil quality. It also helps in conservation of soil profile. The vermicompost or "Black Gold" produced by the earthworm has an endless demand for consumer, since there are no competitors or manmade factories that can ever duplicate the elements of 'Black Gold'. This product can insulate the plant root from extreme temperature, reduce erosion, control weeds and finally increases the fertility of the soil ${ }^{5}$. Earthworm can accelerate the rate of decomposition from $25 \%$ to $40 \%{ }^{4,7,19,20}$.

From the above discussion it can be concluded that that the earthworm is a keystone species among soil invertebrates which affects the agroecosystem and forest ecosystem to a large extent. A good population of earthworm increases the productivity of the agricultural fields, i.e., it helps in production of more food grains. However, its population and biomass in the soil mainly depends upon the physical and 
chemical nature of the soil itself, like temperature, root biomass, $\mathrm{pH}$ and moisture content etc ${ }^{3,22}$. Land invertebrate fauna (surface dwellers) from Similipal Biosphere Reserve (SBR) has been reported earlier $13,14,15,16$. But no literature is available on the earthworms of soil of SBR that has different forest types at various altitudes having varied habitats. Therefore, in the present study emphasis has been on root biomass and temperature of the soil. The results of the above experiments will reflect which type of ecosystem is more disturbed and which one is less disturbed basing on the density or richness of earthworms in these terrestrial ecosystems.

\section{MATERIALS AND METHODS}

The study area covers the transition (peripheral) as well as buffer zones of South-eastern part of Similipal Biosphere Reserve (SBR). Similipal Biosphere Reserve is located (latitude $20^{\circ} 17^{\prime}-22^{\circ} 34^{\prime} \mathrm{N}$ and longitude $85^{\circ} 40^{\prime}-87^{\circ} 10^{\prime} \mathrm{E}$ ) in the central part of Mayurbhanj district of Odisha state in India.

The soil samples were collected from five places of each study sites of different altitudes in different seasons (July-October: Rainy season; November-February: Winter season; and March-June: Summer season) for consecutive 3 years from 2013-2016. For collection of samples, soil block of 25 $\times 25 \times 30 \mathrm{~cm}$ were dug up by crowbar and ten replicas (for each season of each year) were made for each site of study area ${ }^{1}$. Laboratory thermometer was used to measure the temperature $\left({ }^{0} \mathrm{c}\right)$ of soil as per Saxena (1990) at each study site during collection of samples (soil and root biomass and earthworm). For plant root biomass analysis, a quadrate of $12 \mathrm{~cm} \mathrm{x} 12 \mathrm{~cm} \mathrm{x} 12$ $\mathrm{cm}$ size was placed at the site of earthworm sample collection and from that quadrate root was collected and weighed $(\mathrm{g})$ by balance ${ }^{17}$. The root biomass (in $\mathrm{g}$ ) from different locations was compared with density and biomass of earthworm of the same location. The soil masses were taken out and from that earthworms observed visually were collected out by handpicked method ${ }^{6,18}$. They were kept in small plastic jars which contain 5\% formalin for preservation. After collection and preservation by above procedure, they were soaked by a blotting paper before measurement of weight (biomass) ( $\mathrm{g}$ fresh wt.) of the samples by a monopan balance. To convert the soil block area into one square metre, 16 was multiplied with each data obtained from area of $25 \times 25 \mathrm{~cm}$ for the density study.

Differences among mean root biomass and temperature of soil in relation to different altitudes of SBR in different seasons of a year were determined by twoway analysis of variance (ANOVA) ${ }^{2}$. A difference was considered to be statistically significant if $\mathrm{p}<0.05$.

\section{RESULTS AND DISCUSSION}

The effects of environmental characteristics (root biomass and temperature of soil) on biomass of 
earthworm were studied in three different seasons (summer, rainy and winter) for 3 years at different altitudes of SBR. As there is no significant difference of data between years, the data of three years were pooled together.

Mean (average) root biomasses were decreased from lower altitude to higher altitude in all three seasons of the year (rainy, winter and summer). But an exceptional case was observed at study site Katuria and Hadguth in winter season, i.e., mean root biomass at Katuria (23.54 g) and Hadguth (25.31 g) was more than the study site at Debkund (20.08 g), though Katuria and Hadguth are present at higher altitude than the Debkund study site (Table: 1).

It was observed that mean temperature of soil was highest in summer. Then it decreases in rainy and further decreases in winter season at all five study site of study area. An exceptional case was observed at study site Debkund, i.e., mean temperature of soil was more in rainy $\left(30.13{ }^{\circ} \mathrm{c}\right)$ than that of summer season $\left(28.82{ }^{\circ} \mathrm{c}\right.$ ) (Table: 1). There was no significant difference of mean temperature of soil among different altitudes of study area (Table: 3 ).

Mean biomasses of earthworm were decreases from lower altitudes to higher altitude in all three seasons of the year. But an exceptional case was observed at study site Katuria and Hadguth in rainy season, i.e., mean biomass of earthworm at Katuria (34.86 g) was more than the study site at Hadguth (39.44 g), though Katuria is present at higher altitude than the Hadguth study site (Table: 1). This disparity may due to higher standard deviation values. Two agro - forestry based plots in Mizoram are significantly affected by rainfall and moisture content of the soil. The findings of Lalthanzara et al. (2011) are that the biomass of earthworm of two agro - forestry based plots in Mizoram support the present result. 
Table 1: Average density (number) of earthworm, root biomass $(\mathrm{g})$ and temperature $\left({ }^{\circ} \mathrm{c}\right)$ (3 years) of soil at different altitudes of SBR in different season (Summer, Rainy and Winter)

\begin{tabular}{|l|l|c|c|c|}
\hline $\begin{array}{l}\text { Study area of } \\
\text { different altitudes }\end{array}$ & Parameter & Summer & Rainy & Winter \\
\hline Balma(133 mASL) & Biomass of earthworm & 16.33 & 49.93 & 22.45 \\
\cline { 2 - 5 } & Root biomass of soil & 19.18 & 32.89 & 31.06 \\
\cline { 2 - 5 } & Temperature of soil & 27.53 & 24.66 & 17.96 \\
\hline \multirow{3}{*}{ Debkund(190 mASL) } & Biomass of earthworm & 15.11 & 41.02 & 20.99 \\
\cline { 2 - 5 } & Root biomass of soil & 18.31 & 30.12 & 20.08 \\
\cline { 2 - 5 } & Temperature of soil & 28.82 & 30.13 & 17.56 \\
\hline \multirow{3}{*}{ Hadguth(222 mASL) } & Biomass of earthworm & 13.85 & 39.44 & 19.55 \\
\cline { 2 - 5 } & Root biomass of soil & 16.24 & 28.56 & 25.31 \\
\cline { 2 - 5 } & Temperature of soil & 29.93 & 27.06 & 17.99 \\
\hline \multirow{3}{*}{ Katuria(242 mASL) } & Biomass of earthworm & 13.40 & 34.86 & 20.12 \\
\cline { 2 - 5 } & Root biomass of soil & 15.29 & 25.98 & 23.54 \\
\cline { 2 - 5 } & Temperature of soil & 29.39 & 25.59 & 17.79 \\
\hline \multirow{3}{*}{ Nato(326 mASL) } & Biomass of earthworm & 12.23 & 32.38 & 17.98 \\
\cline { 2 - 5 } & Root biomass of soil & 14.29 & 35.55 & 19.71 \\
\cline { 2 - 5 } & Temperature of soil & 29.96 & 26.69 & 17.46 \\
\hline
\end{tabular}

Table 2: Summary of computations for two-way analysis of variance (F - test) of data of root biomass of soil at different altitudes of SBR in different seasons (Summer, Rainy and Winter)

\begin{tabular}{|l|c|c|c|l|}
\hline Source of Variation & $\begin{array}{c}\text { Degree of } \\
\text { Freedom }\end{array}$ & $\begin{array}{c}\text { Sum of } \\
\text { squares }\end{array}$ & Mean square & Variance ratio $(\mathrm{F})$ \\
\hline Between Altitudes & $\mathrm{r}-1=5-1=4$ & $\mathrm{RSS}=64.76$ & $\mathrm{RMS}=16.19$ & $\begin{array}{l}\mathrm{F}_{\mathrm{CR}}=1.39 \\
\mathrm{~F} \propto 2.84, \text { at } 0.05 \text { level }\end{array}$ \\
\hline Between Seasons & $\mathrm{c}-1=3-1=2$ & $\mathrm{CSS}=487.36$ & $\mathrm{CMS}=243.68$ & $\begin{array}{l}\mathrm{F}_{\mathrm{CC}}=20.96 \\
\mathrm{~F}=4.46 \text {, at } 0.05 \text { level }\end{array}$ \\
\hline Error & $(\mathrm{r}-1)(\mathrm{c}-1)=8$ & $\mathrm{ESS}=92.98$ & $\mathrm{EMS}=11.62$ & \\
\hline Total & $(\mathrm{r} \mathrm{c})-1=14$ & $\mathrm{TSS}=645.11$ & & \\
\hline
\end{tabular}


Table 3: Summary of computations for two-way analysis of variance ( $F$ - test) of data of temperature of soil at different altitude of SBR in different seasons (Summer, Rainy and Winter)

\begin{tabular}{|l|c|c|c|c|}
\hline Source of Variation & $\begin{array}{c}\text { Degree of } \\
\text { Freedom }\end{array}$ & $\begin{array}{c}\text { Sum of } \\
\text { squares }\end{array}$ & Mean square & Variance ratio $(\mathbf{F})$ \\
\hline Between Altitudes & $\mathrm{r}-1=5-1=4$ & $\mathrm{RSS}=7.72$ & $\mathrm{RMS}=1.93$ & $\begin{array}{l}\mathrm{F}_{\mathrm{CR}}=1.12 \\
\mathrm{~F}=3.84, \text { at } 0.05 \text { level }\end{array}$ \\
\hline Between Seasons & $\mathrm{c}-1=3-1=2$ & $\mathrm{CSS}=361.65$ & $\mathrm{CMS}=180.82$ & $\begin{array}{l}\mathrm{F}_{\mathrm{CC}}=105.12 \\
\mathrm{~F}=4.46, \text { at } 0.05 \text { level }\end{array}$ \\
\hline Error & $(\mathrm{r}-1)(\mathrm{c}-1)=8$ & $\mathrm{ESS}=13.76$ & $\mathrm{EMS}=1.72$ & \\
\hline Total & $\mathrm{r} \mathrm{c})-1=14$ & $\mathrm{TSS}=383.143$ & & \\
\hline
\end{tabular}

From two-way analysis of variance (ANOVA) study, it was observed that both the temperature and root biomass of soil were significantly different $(\mathrm{p}<0.05)$ among different seasons. But among altitudes they were not significantly different (Table: 2 and 3). According to Karmegam and Daniel (2007) earthworm population decreases with increase in the soil temperature at Dindigul district of Tamilnadu, India. The soil temperature plays an important role in the maintenance of earthworm population at Odisha ${ }^{21}$ and Madras ${ }^{9}$. In the present study there was also a seasonal variation in earthworm population in study sites and peak density was observed during the monsoon (rainy) season due to moderate temperature, so biomass of earthworm also more. As the root biomass increases density and biomass of earthworm also increases. Plant root increases the soil moisture and some time dead tissue of root epidermis in soil also increases the organic matter of soil. Both the soil moisture and root biomass favours the growth of earthworms ${ }^{12}$.

\section{CONCLUSION}

From the present study it can be concluded that, soil containing more root biomass supports more numbers of earthworm, so biomass of earthworm also more. Root biomass increases organic matter and moisture content of soil, which support the increase in biomass of earthworms. Again present study indicates amount of root biomass increases from lower to higher altitudes, from summer to winter seasons and from winter to rainy season. So biomass of earthworm increases from lower to higher altitudes.

Present study provides a conclusion that soil having moderate range of temperature supports more numbers of earthworms. According to this study the temperature of soil in rainy season is in between temperature of soil in summer and winter season. So it can be concluded that rainy season is favourable for increase in 
the earthworm population than other seasons of the year at SBR.

\section{REFERENCES}

1. Anderson, J.M. \& J.S.I. Ingram, 1992. Tropical Soil Biology and Fertility: A Handbook of Methods, CAB International, Wallingford, UK.

2. Croxton, F.E., D.J. Cowden \& S. Klein, 1982. Applied General Statistics. Prentice - Hall of India Pvt. Ltd., New Delhi.

3. Dash, M.C., 2005. Fundamentals of Ecology. Tata McGraw-Hill Publishing Company Limited, New Delhi.

4. Dash, M.C. \& B.K. Senapati, 1980. Cocoon morphology, hatching and emergence pattern in tropical earthworms. Pedobiologia, 20: 316-324.

5. Dash, M.C. \& B.K. Senapati, 1985. Vermitechnology: Potentiality of Indian earthworms for vermicomposting and vermifeed, In: Mishra, M.M. and Kapoor, K.K. (eds). Proc. of the Natl. Sem. on "Current Trends in Soil Biology", HAU, pp: 61-69.

6. Dash, M.C. \& U.C. Patra, 1977. Density, biomass and energy budget of tropical earthworm population from a grassland site in Orissa, India. Revue d'Ecologie et Biologie du Sol., 14(3): 461-471.

7. Edwards, C.A. \& G.N. Heath, 1975. Studies on leaf litter breakdown. The influence of leaf age. Pedobiologia, 15: 348-354.

8. Edwards, C.A., P.J. Bohlen, D.R. Linden, \& S. Subler, 1995. Earthworms in Agroecosystems. In: Hendrix, P.F. (ed). Earthworm Ecology and Biogeography in North America. Lewis Publisher, Boca Raton, pp. 185-206.

9. Ismail, S.A. and Murthy, V.A. (1985) Distribution of earthworms in Madras. Proc.Indian Acad. Sci., 94: 557-566.

10. Karmegam, N. and Daniel, T. (2007) Effect of Physico-chemical parameters on earthworm abudance: A Quantitative Approach. Journal of Applied Sciences Research, 3(11): 13691376.

11. Lalthanzara H., S.N. Ramanujam \& L.K. Jha, 2011. Population dynamics of earthworms in relation to soil physico-chemical parameters in agroforestry systems of Mizoram, India. J. Environ. Biol., 32: 599605.

12. Lavelle, P., Dangerfield, M., Fragoso, C., Eschenbrenner, V., Lopez-Hernandez, D., Pashansi, B. and Brussard, L., 1994. The relationship between soil microfauna and soil tropical fertility, In: The biological management of tropical soil fertility (Eds.: P.L. Woomer and M.J. Swift). John Wiley. West Sussex, New York, pp. 137-170.

13. Lenka, M.K., N. Mohanty, B.C. Guru \& S. Giri, 2010. A study on soil invertebrates in different terrestrial ecosystems of Similipal Biosphere Reserve, Mayurbhanj, Orissa. The Bioscan, 5(3): 419-422.

14. Lenka, M.K., N. Mohanty \& B.C. Guru, 2017a. A study on density and biomass of earthworm in different altitudes of south-eastern part of Similipal Biosphere Reserve, Mayurbhanj, Odisha. J. Adv. Zool., 38(2): 121-127.

15. Lenka, M.K., N. Mohanty \& B.C. Guru, 2017 b. Effects of altitude, root biomass and temperature of soil on density of earthworm in south-eastern part of Similipal Biosphere Reserve, Mayurbhanj, Odisha. Indian Journal of Applied Research, 7(12): 253.

16. Ramakrishna, P.S., S.J. Siddiqui, P. Sethy \& S. Dash, 2006. Faunal Resources of Similipal Biosphere Reserve, Mayurbhanj, Orissa, Zoological Survey of India, Kolkata.

17. Saxena, M.M., 1990. Environmental Analysis: Water, Soil and Air. $2^{\text {nd }}$ ed., Agro Botanical Publishers, New Delhi.

18. Senapati, B.K. \& M.C. Dash, 1981. Effect of grazing on the elements of production in the vegetation and oligochaete components of a tropical pasture land. Revue d'Ecologie et Biologie du Sol., 18: 487-505. 
19. Senapati, B.K. \& M.C. Dash, 1982. Earthworm as a waste conditioner. I.E. Journal, 2: 5357.

20. Senapati, B.K. \& M.C. Dash, 1984a. Functional role of earthworms in the decomposer subsystem. Trop. Ecol., 25(1): 52-72.
21. Senapati, B.K. and M.C. Dash, 1984b. Influence of soil temperature and moisture on the reproductive activity of tropical earthworms of Orissa. J. Soil Biol. Ecol., 4: 13-21.

22. Sharma, P. D., 2005. Ecology and Environment. Rastogi Publications, Meerut. 